\title{
Front Matter: Volume 7490
}

, "Front Matter: Volume 7490," Proc. SPIE 7490, PIAGENG 2009: Intelligent Information, Control, and Communication Technology for Agricultural Engineering, 749001 (10 July 2009); doi: 10.1117/12.837330

SDIE Event: International Conference on Photonics and Image in Agriculture SPIE. Engineering (PIAGENG 2009), 2009, Zhangjiajie, China 


\title{
PROCEEDINGS OF SPIE
}

\section{PIAGENG 2009}

\section{Intelligent Information, Control, and Communication Technology for Agricultural Engineering}

\author{
Honghua Tan \\ Qi Luo
}

Editors

11-12 July 2009

Zhangjiajie, China

Organized by

IITA-Intelligent Information Technology Application Research Association (China)

IEEE SMC Technical Committee on Education Technology and Training (United States)

Wuhan Institute of Technology (China)

Asia Pacific Human-Computer Interaction Center (Hong Kong, China)

Sponsored by

IITA—Intelligent Information Technology Application Research Association (China)

Published by

SPIE

Volume 7490 
The papers included in this volume were part of the technical conference cited on the cover and title page. Papers were selected and subject to review by the editors and conference program committee. Some conference presentations may not be available for publication. The papers published in these proceedings reflect the work and thoughts of the authors and are published herein as submitted. The publisher is not responsible for the validity of the information or for any outcomes resulting from reliance thereon.

Please use the following format to cite material from this book:

Author(s), "Title of Paper," in PIAGENG 2009: Intelligent Information, Control, and Communication Technology for Agricultural Engineering, edited by Honghua Tan, Qi Luo, Proceedings of SPIE Vol. 7490 (SPIE, Bellingham, WA, 2009) Article CID Number.

ISSN 0277-786X

ISBN 9780819478016

Published by

SPIE

P.O. Box 10, Bellingham, Washington 98227-0010 USA

Telephone +1 3606763290 (Pacific Time) · Fax +1 3606471445

SPIE.org

Copyright (@ 2009, Society of Photo-Optical Instrumentation Engineers

Copying of material in this book for internal or personal use, or for the internal or personal use of specific clients, beyond the fair use provisions granted by the U.S. Copyright Law is authorized by SPIE subject to payment of copying fees. The Transactional Reporting Service base fee for this volume is $\$ 18.00$ per article (or portion thereof), which should be paid directly to the Copyright Clearance Center (CCC), 222 Rosewood Drive, Danvers, MA 01923. Payment may also be made electronically through CCC Online at copyright.com. Other copying for republication, resale, advertising or promotion, or any form of systematic or multiple reproduction of any material in this book is prohibited except with permission in writing from the publisher. The CCC fee code is 0277-786X/09/\$18.00.

Printed in China.

Publication of record for individual papers is online in the SPIE Digital Library.

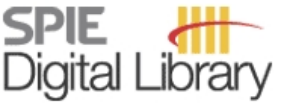

SPIEDigitalLibrary.org

Paper Numbering: Proceedings of SPIE follow an e-First publication model, with papers published first online and then in print and on CD-ROM. Papers are published as they are submitted and meet publication criteria. A unique, consistent, permanent citation identifier (CID) number is assigned to each article at the time of the first publication. Utilization of CIDs allows articles to be fully citable as soon they are published online, and connects the same identifier to all online, print, and electronic versions of the publication. SPIE uses a six-digit CID article numbering system in which:

- The first four digits correspond to the SPIE volume number.

- The last two digits indicate publication order within the volume using a Base 36 numbering system employing both numerals and letters. These two-number sets start with 00, 01, 02, 03, 04 , 05, 06, 07, 08, 09, OA, OB ... 0Z, followed by 10-1Z, 20-2Z, etc.

The CID number appears on each page of the manuscript. The complete citation is used on the first page, and an abbreviated version on subsequent pages. Numbers in the index correspond to the last two digits of the six-digit CID number. 


\section{Contents}

xii Conference Committee

$\mathrm{xv}$ Introduction

PIAGENG 2009: INTELLIGENT INFORMATION, CONTROL, AND COMMUNICATION TECHNOLOGY FOR AGRICULTURAL ENGINEERING

749002 An integrated ESDA-based simulation on spatial distribution of rural land conflicts at provincial scale [7490-01]

Y. Liu, L. Wan, L. Sun, Nanchang Univ. (China)

749003 Wireless intelligent alarm technology with pyroelectric infrared sensor [7490-02]

$X$. Chen, Nanjing Univ. of Information Science \& Technology (China)

749004 Retrieval of land surface temperature in Yangtze Delta by using split-window algorithm and AVHRR data [7490-03]

S. Zha, Nantong Univ. (China); Q. Wang, Hubei Univ. (China); M. Sheng, Nantong Univ.

(China); Y. Ding, Nanjing Univ. of Information Science \& Technology (China)

749005 A land cover classification system for use in global change modeling and based on BISE algorithm [7490-04]

Q. Wang, H. Zhang, H. Sun, Hubei Univ. (China); J. Li, Institute of Geographical Sciences \& Natural Resources Research (China)

749006 Evaluation on vegetation net primary productivity using MODIS data in Inner Mongolia [7490-05]

Y. Bao, G. Bao, L. Guo, Inner Mongolia Normal Univ. (China); Q. Hai, Inner Mongolia Normal Univ. (China) and Bao Tou Normal Univ. (China)

749007 Visualized modeling plafform for virtual plant growth and monitoring on the internet [7490-06]

D. Zhou, F. Tian, P. Ren, Suzhou Vocational Univ. (China)

749008 Design and application of quick computation program on fractal dimension of land-use types [7490-07]

X. Mei, Q. Wang, Q. Wang, Hubei Univ. (China); J. Liu, Wuhan Univ. (China)

749009 The analysis on the changes of the consumption structure of rural residents in China [7490-08]

F. LU, M. LU, Y. Fan, Zhengzhou Univ. (China)

7490 0A A new type of LAN embedded NC system [7490-09]

Z. Zhu, East China Institute of Technology (China); X. Feng, Guilin Univ. of Electronic Technology (China); R. Wang, East China Institute of Technology (China) 
7490 OB A novel dynamic mesh simplification algorithm based on error control [7490-10]

Y. Wu, Shanghai Univ. (China) and East China Univ. of Technology (China); W. Wan, B. Cui,

L. Jin, Shanghai Univ. (China)

7490 0C Design of PID control system based on LabVIEW [7490-11]

W. Jiang, East China Institute of Technology (China) and Anhui Univ. (China); F. Yuan, East China Institute of Technology (China)

7490 OD Research of the measurement method of vortex flowmeter [7490-12]

W. Jiang, East China Institute of Technology (China) and Anhui Univ. (China); F. Yuan, East China Institute of Technology (China); Y. Li, East China Institute of Technology (China) and Huazhong Univ. of Science and Technology (China)

7490 OE Induction machine Direct Torque Control system based on fuzzy adaptive control [7490-13] S. Li, Northeastern Univ. (China); Y. Yu, Z. Jiao, Northeastern Univ. (China) and Air Force Aviation Univ. of PLA (China); S. GU, Northeastern Univ. (China)

7490 OF Design of precision measurement circuits for the relative humidity [7490-15]

Y. Wang, G. Gao, Z. Sha, Hebei Univ. of Science and Technology (China)

7490 OG A car theft deterrent system research based on ARM9 [7490-16]

K. Zhang, J. Liu, L. Fan, Shaanxi Univ. of Science \& Technology (China)

$7490 \mathrm{OH} \quad$ Study on quality controlling of low-sugar preserved kiwi fruit [7490-17] K. Zhang, Q. Wang, Shaanxi Univ. of Science \& Technology (China)

$7490 \mathrm{Ol} \quad$ Research of pulse signal processing based on sleep-monitoring alarm system [7490-18] K. Zhang, Y. Zeng, Shaanxi Univ. of Science \& Technology (China)

7490 0J Research on application of modern household design and intellective household system [7490-19]

K. Zhang, Y. Zeng, J. Fan, Shaanxi Univ. of Science \& Technology (China)

7490 OK Research and functional realization of marine environment information support system [7490-20]

Y. Tang, Y. Hao, Harbin Engineering Univ. (China); X. Wei, Hunan Space Agency (China)

$7490 \mathrm{OL} \quad$ Energy measurement device wiring detection and examination training system design [7490-21]

X. Zhang, Taiyuan Univ. of Technology (China); G. Liu, Lvliang Power Supply Branch (China)

7490 OM A study on operation efficiency evaluation based on firm's financial indexes and benchmark selection: take China Unicom as an example [7490-22] Z. Wu, Z. Tian, H. Liu, R. Huang, G. Zhu, Xi'an Univ. of Technology (China)

$7490 \mathrm{ON}$ The research on recognition methods of aphid objects in complex backgrounds [7490-23] H.-Y. Zhao, J.-H. Zhang, Northwest A\&F Univ. (China) 
749000 An advanced LS algorithm for monitoring ground deformation over large area using ALOS PALSAR data [7490-24]

H. Wu, Institute of Remote Sensing Applications (China), Ctr. for Earth Observation and Digital Earth (China), and Graduate Univ. of the Chinese Academy of Sciences (China);

C. Wang, H. Zhang, Y. Tang, Ctr. for Earth Observation and Digital Earth (China)

7490 OP Intelligent annunciator for solar water heater [7490-25]

$X$. Chen, Nanjing Univ. of Information Science \& Technology (China)

$74900 Q \quad$ A simulation method for the fruitage body [7490-26]

L. Lu, W. Song, L. Wang, East China Institute of Technology (China)

7490 OR Construction of the virtual architecture community environment with VRML and JavaScript [7490-27]

X. Feng, P. Wang, Zhejiang Ocean Univ. (China)

7490 OS An intelligent environment monitoring system based on wireless sensor networks [7490-28] M. Cao, H. Wang, D. Peng, K. Jia, Lanzhou Univ. of Technology (China)

7490 OT Research and exploration of product innovative design for function [7490-29]

D. Wang, Z. Wei, Y. Wang, R. Tan, Hebei Univ. of Technology (China)

7490 OU An improved enhancement algorithm based on OTSU adaptive threshold and fuzzy set theory for robot digital roadmap [7490-30]

Y. Luo, H. Yang, Chongqing Univ. of Posts and Telecommunications (China)

7490 OV Study of R-group positively charged amino acids' UV [7490-31]

T. Tian, Dezhou Univ. (China); G. Liu, Dezhou Univ. (China) and Shandong Univ. (China); X. Meng, X. Tan, Dezhou Univ. (China); Y. Liu, Dezhou Univ. (China) and Shandong Univ. (China)

7490 OW Observations of cloud condensation nuclei in Mt. Huang: instrumentation and early observations [7490-32]

K. Chen, Y. Yin, C. Chen, W. Yang, W. Deng, Z. Hu, F. Wu, Nanjing Univ. of Information Science \& Technology (China)

7490 0X Airborne measurements of the spatial and spectral distributions of aerosol particles over Hebei area, northern China [7490-33]

Y. Yin, Nanjing Univ. of Information Science \& Technology (China); Y. Duan, Hebei Provincial Office of Weather Modification (China); Y. Zhang, Nanjing Univ. of Information Science \& Technology (China); L. Shi, Hebei Provincial Office of Weather Modification (China); Z. Yang, Nanjing Univ. of Information Science \& Technology (China); Z. WU, Y. Li, Hebei Provincial Office of Weather Modification (China)

7490 OY Stress analysis of bearings of main eccentric shaft for width mill [7490-34]

X. Feng, Y. Liu, Y. Cui, Z. Jiang, Zhengzhou Institute of Aeronautical Industry Management (China)

$74900 Z$ FE analysis of dynamic characteristics for mill's liners [7490-35]

X. Feng, Y. Cui, Z. Jiang, T. Hou, Zhengzhou Institute of Aeronautical Industry Management (China) 
749010 FE analysis of drive process of piezoelectric motor [7490-36]

Y. Cui, X. Feng, Z. Jiang, Zhengzhou Institute of Aeronautical Industry Management (China)

749011 Design of an intelligent inquiry system for agriculture information [7490-37]

B. Cui, Shandong Univ. of Science and Technology (China)

749012 Building service oriented applications for agricultural production: a flood forecast and control example [7490-38]

Y. Su, Institute of Scientific and Technical Information (China) and Tsinghua Univ. (China);

Z. Jin, Tsinghua Univ. (China); G. Peng, X. Li, Institute of Scientific and Technical Information (China)

749013 The applications of mobile telecommunications in new rural areas [7490-39]

X. Chen, T. Lu, Beijing Univ. of Posts and Telecommunications (China)

749014 Multiresolution blind source separation method using sparsity for harmonic retrieval [7490-40]

R. Li, Henan Univ. of Technology (China); F. Wang, China Electronics Technology Group Corp. (China)

749015 Information extraction from semi-structured webpage based on DOM tree [7490-41]

W.-D. Li, Y. Dong, Hebei Univ. of Economics \& Business (China)

749016 Analysis on some factors affecting MIMO in tunnel [7490-42]

H. Zheng, X. Nie, Z. XU, China Univ. of Mining and Technology (China)

749017 A mixed approach for nonlinear equations based on simple smooth penalty function and filled function [7490-43]

W. Wang, Shanghai Second Polytechnic Univ. (China); Y. Shang, Henan Univ. of Science and Technology (China); L. Zhang, Shanghai Univ. (China)

749018 Multi-mobile-robot network control system based on wireless distribution system [7490-44] S. Guo, Y. Li, Y. He, Shanghai Univ. (China)

749019 Architecture based service development for service reuse of varying levels of granularity [7490-45]

C. Wang, Weifang Univ. (China)

74901 1A Study on supply chain management in tourism e-commerce [7490-46]

Y. Hu, Henan Institute of Engineering (China); S. Wu, H. Ma, Zhengzhou College of Animal Husbandry (China)

7490 1B The hermitian positive definite solution of matrix equations and its application [7490-47] X. Liu, H. Li, Shandong Univ. of Technology (China)

7490 1C An anisotropic diffusion equation based on multi-structural elements morphology [7490-48] J.-P. Huang, Taizhou Univ. (China)

7490 1D Measurement of grain moisture with a coplanar electrode capacitance probe [7490-49]

L. Yang, Y. Tan, L. Dong, Z. Mao, China Agricultural Univ. (China) 
$74901 \mathrm{E} \quad$ Study on the idity fuzzy neural network controller based on improved genetic algorithm of intelligent temperature control system in vegetable greenhouse [7490-50]

S. Zhang, H. Yuan, Y. Zhou, N. Wang, Agricultural Univ. of Hebei (China)

7490 IF A shot gradual changes detection algorithm based on adjacent scale wavelet transform [7490-51]

M. Huang, J. Jiang, S. Liang, Y. Zhang, Zhengzhou Univ. of Light Industry (China)

7490 1G Design of the fertilization expert system based on plug-in technology [7490-52]

Y. Xu, Southwest Univ. (China); S. Yang, Chongqing Institute of Meteorological Science (China)

$74901 \mathrm{H} \quad$ The governance mechanism of industrial clusters based on the analysis of the demand shock [7490-53]

S. Wang, Zhejiang Gongshang Univ. (China)

749011 An optimized item-based collaborative filtering recommendation algorithm based on item genre prediction [7490-54]

D.-J. Zhang, Wenzhou Vocational and Technical College (China)

$74901 \mathrm{~J} \quad$ Application of XML in real-time data warehouse [7490-55]

Y. Zhao, B. Wang, L. Liu, S. Ye, Xiamen Univ. (China)

7490 1K A novel filled function for unconstrained global optimization [7490-56]

W. Wang, Shanghai Second Polytechnic Univ. (China); Y. Shang, Henan Univ. of Science and Technology (China); L. Zhang, Shanghai Univ. (China)

$74901 \mathrm{~L} \quad$ The intelligent management and control technology for enterprise based on electrical characteristics [7490-57]

P. Dong, F. Dai, T. Zhao, T. Li, Zhengzhou Information Science and Technology Institute (China)

$74901 \mathrm{M} \quad$ Research on prediction of agricultural machinery total power based on grey model optimized by genetic algorithm [7490-58]

Y. Xie, Wuhan Polytechnic Univ. (China); M. Li, State Grid Electric Power Research Institute (China); J. Zhou, C. Zheng, Wuhan Polytechnic Univ. (China)

$74901 \mathrm{~N} \quad$ An analysis of the early-warning system in emerging markets for reducing the financial crisis [7490-59]

X. Shen, X. Song, Yanshan Univ. (China)

749010 Time-frequency analysis of dynamic light scattering signals of particles [7490-60] Z. Li, Shandong Univ. of Technology (China); W. Li, Yiyang Bureau of Land and Resources (China); J. Shen, B. Tan, Shandong Univ. of Technology (China)

7490 IP The application of stepwise regression method in discussing the relation between interest rate and inflation rate [7490-61]

X. Xu, Y. Chen, H. Jia, South China Agricultural Univ. (China)

$74901 Q \quad$ Study of filtering algorithm for agile projectile's attitude determination [7490-62]

Y. Wang, Z. Liu, J. Chen, C. Song, Beijing Institute of Technology (China) 
$74901 R \quad$ UMA/GAN network architecture analysis [7490-63]

L. Yang, W. Li, C. Deng, Y. LV, Univ. of Electronic Science and Technology of China (China)

7490 is Research of rural power grids harmonics monitoring system based on technology of LabVIEW [7490-64]

Y. Zhou, Y. Xie, S. Zhang, Agricultural Univ. of Hebei (China)

7490 1T An uncertainty algorithm for multivariate decision tree construction [7490-65]

Y. Qiu, Liaoning Technical Univ. (China); X. E, Liaoning Univ. of Technology (China); L. Shao, S. Sun, Liaoning Technical Univ. (China)

$74901 \mathrm{U} \quad$ Elliptic numerical ranges of $4 \times 4$ reducible companion matrices [7490-66]

X. Liu, Z. Meng, Y. Zhou, H. Li, Shandong Univ. of Technology (China)

$74901 \mathrm{~V}$ The judgment of the nonsingularity on scaled factor circulant matrices [7490-67]

X. Liu, Shandong Univ. of Technology (China); X. Ba, Shandong Drug and Food Vocational College (China); P. Wei, H. Li, Shandong Univ. of Technology (China)

7490 1W Research of negotiation in network trade system based on multi-agent [7490-68]

J. Cai, Hang Zhou Institute of Commerce (China); G. Wang, H. Wu, Zhejiang Gongshang Univ. (China)

7490 1X A novel MD video coding scheme for ROI based on H.264 [7490-69] M. M. Zhang, W. K. Liu, North China Univ. of Technology (China); R. B. Wang, North China Univ. of Technology (China) and Beijing Jiaotong Univ. (China); H. H. Bai, Y. X. Chen, Beijing Institute of Technology (China)

7490 IY Research on some issues of software testing technology [7490-70] H. Zhou, Huaiyin Teachers College (China)

749012 A methodology for the simulation of digital-to-analog converters [7490-71] L. Liu, Changsha Univ. of Science and Technology (China); W. Li, Hunan Univ. (China)

749020 Controlling the producer-consumer problem using constant-time epistemologies [7490-72] L. Liu, Changsha Univ. of Science and Technology (China); W. Li, Hunan Univ. (China)

$749021 \quad$ Decoupling erasure coding from massive multiplayer online role-playing games in model checking [7490-73]

L. Liu, Changsha Univ. of Science and Technology (China); W. Li, Hunan Univ. (China)

749022 Pseudorandom reliable algorithms and their applications to amphibious communication [7490-74]

W. Huang, Hunan Univ. of Science and Technology (China); J. Li, Hunan Univ. (China)

749023 The influence of omniscient technology on cryptography [7490-75]

W. Huang, Hunan Univ. of Science and Technology (China); J. Li, Hunan Univ. (China)

749024 A development of the lookaside buffer with Dido [7490-76]

Y. Huang, Changsha Univ. of Science and Technology (China); L. Gan, Hunan Univ. (China) 
749025 A methodology for the refinement of information retrieval systems [7490-77]

Y. Huang, Changsha Univ. of Science and Technology (China); L. Gan, Hunan Univ. (China)

749026 The effect of virtual modalities on e-voting technology [7490-78]

Y. Huang, Changsha Univ. of Science and Technology (China); L. Gan, Hunan Univ. (China)

749027 Grassland dynamics and its driving forces in western Northeast China [7490-79]

L. Chang, Northeast Institute of Geography and AgroEcology (China); J. Yang, Northeast

Institute of Geography and Agroecology (China) and Graduate Univ. of the Chinese

Academy of Sciences (China); S. Zhang, Y. Zhang, Northeast Institute of Geography and AgroEcology (China)

749028 The application of element-free Galerkin method in the problem of the cantilever beam [7490-80]

W. Ji, M. Xia, W. Guan, H. Zeng, Yanshan Univ. (China)

749029 Application of neural network to qualitatively analyze Raman spectra of mixtures [7490-81] G. Li, China Univ. of Geosciences (China)

7490 2A Parallel association rule mining for image data [7490-82]

J. Sun, W. Pan, Liaoning Technical Univ. (China)

7490 2B Organizational coevolutionary classifiers with fuzzy logic used in intrusion detection [7490-83]

Z. Chen, North China Institute of Science and Technology (China)

7490 2C Safe drinking water projects integrated information system for rural areas [7490-84] X. Song, Y. Zhao, C. Liu, Z. Song, Hebei Univ. of Science and Technology (China)

7490 2D Using an improved association rules mining optimization algorithm in web-based mobile-learning system [7490-85]

Y. Huang, J. Chen, Wuhan Univ. (China); S. Xiong, Huazhong Normal Univ. (China)

$74902 \mathrm{E} \quad$ Research on a piezoelectric mechanism with inertial movement [7490-86]

X. Li, J. Liu, Jilin Univ. (China)

$74902 \mathrm{~F} \quad$ Actuarial models of life insurance with stochastic interest rate [7490-87]

X. Wei, P. Hu, Wuhan Univ. of Science and Engineering (China)

$74902 \mathrm{G}$ Simulation of temporal and spatial distribution of required irrigation water by crop models and the pan evaporation coefficient method [7490-88]

Y. Yang, Y. Yang, S. Han, Institute of Genetics and Developmental Biology (China); Y. Hu, Hebei Provincial Academy of Water Resources (China)

$74902 \mathrm{H} \quad$ Study on regional innovation system of agricultural science technology park: from a perspective of complex adaptive systems theory [7490-89]

X. Li, Wuhan Univ. (China) and Wuhan Polytechnic Univ. (China); X. Wang, Wuhan Univ. (China)

$749021 \quad$ Financial risk early-warning based on RS-SVM hybrid model [7490-90]

D. Niu, S. Hou, Y. Zhang, X. Sun, North China Electric Power Univ. (China) 
7490 2J Biological nitrification process simulation in groundwater with dissolved oxygen controller [7490-91]

J. Zuo, Harbin Univ. of Commerce (China)

7490 2K Address maintenance method of Ethernet routing bridge based on hash algorithm [7490-92] A. Fang, A. Chen, X. Zhang, L. Luo, Nanchang Univ. (China)

$74902 \mathrm{~L} \quad$ Research on suppliers selection for e-commerce alliance [7490-93]

C. Ju, B. Sun, D. Liu, Zhejiang Gongshang Univ. (China)

$74902 \mathrm{M} \quad$ Routing in double layered satellite network [7490-94]

X. Fan, G. Fei, Beijing Institute of Technology (China)

$74902 \mathrm{~N}$ Application of grey relational analysis to agricultural management decision-making [7490-95]

Y. Xie, Wuhan Polytechnic Univ. (China); M. Li, NARI Group Corp. (China); J. Sun, F. Wang, Wuhan Polytechnic Univ. (China)

749020 Noise robust speech recognition based on wavelet-RBF neural network [7490-96]

$X$. Hou, Xi'an Institute of Posts and Telecommunications (China)

7490 2P A new wireless communication system based on ZigBee technology [7490-98]

Z. Qi, Y. Zhang, L. Zhao, Q. Bai, E. Shi, Northeastern Univ. (China)

$74902 Q \quad$ Application of a one-wire digital temperature sensor in the monitoring system of a granary's temperature [7490-99]

H. Ma, X. Wang, X. Zhang, Hebei Univ. of Science and Technology (China)

$74902 R \quad$ Establishing an integrated urban-rural monitoring system against natural disasters [7490-100] $X . X U$, J. Wang, Wuhan Univ. (China)

$749025 \quad$ A novel edge detection method based on adaptive neuro-fuzzy inference system [7490-101]

L. Zhang, M. Xiao, J. Ma, H. Song, Chang'an Univ. (China)

7490 2T Research on L-system based plant simulation platform [7490-102]

L. Yao, F. Yan, S. Wang, Beijing Forestry Univ. (China)

$74902 \mathrm{U} \quad$ Design and analysis of a switching power with high power factor [7490-103]

S. Ma, Y. Xue, Wuhan Univ. of Science and Engineering (China)

$74902 \mathrm{~V}$ Ecological restoration strategy for Yuanmou dry-hot valley based on immune defensive structure [7490-104]

B. Zhang, F. Qin, China West Normal Univ. (China); G. Liu, Institute of Hazards and Environment (China); N. Ai, B. Di, Sichuan Univ. (China)

$74902 \mathrm{~W}$ Experimental study on microscopic evolving process of boiling overheat liquid in boiler under microcracking condition [7490-105]

S. Chen, China Academy of Safety Sciences and Technology (China); X. He, J. Sun, Univ. of Science and Technology of China (China) 
$74902 \mathrm{X}$ Research on flexible customization of MIS process based on workflow management [7490-106]

B. Wang, Zhejiang Gongshang Univ. (China)

$74902 Y \quad B a y e s i a n$ of inductive cognition algorithm for adaptive classification [7490-107]

L. Jin, W. Wan, B. Cui, Y. Wu, Shanghai Univ. (China)

$74902 Z$ An improved algorithm based on multi-weighted and mathematical morphology for rural road extraction [7490-109]

G. XU, D. Zhang, North China Electric Power Univ. (China)

749030 The effect of embedded epistemologies on complexity theory [7490-1 10]

W. Huang, Hunan Univ. of Science and Technology (China); J. Li, Hunan Univ. (China)

749031 Design of a real-time tax-data monitoring intelligent card system [7490-111]

Y. Gu, G. Bi, L. Chen, Southwest Univ. of Science and Technology (China); Z. Wang, Anqing Normal College (China)

749032 Research of a class of wireless communication systems in agricultural engineering [7490-113]

J. Zhao, Beijing Union Univ. (China)

749033 Global asymptotic stability of a class of wireless communication systems in agricultural engineering [7490-114]

J. Zhao, Beijing Union Univ. (China)

749034 Analysis of a class of information systems in agricultural engineering [7490-115]

J. Zhao, Beijing Union Univ. (China)

Author Index 
Downloaded From: https://www.spiedigitallibrary.org/conference-proceedings-of-spie on 25 Apr 2023

Terms of Use: https://www.spiedigitallibrary.org/terms-of-use 


\title{
Conference Committee
}

\author{
Conference Chairs
}

Honghua Tan, Wuhan Institute of Technology (China)

Fan Yang, Wuhan Institute of Technology (China)

Committee Chairs

Weitao Zheng, Wuhan University of Technology (China)

Ben Kwang-Mong Sim, Hong Kong Baptist University

(Hong Kong, China)

Program Committee

Shao Xi, Nanjing University of Posts and Telecommunications (China)

Xueming Zhang, Beijing Normal University (China)

Peide Liu, Shangdong Economic University (China)

Dariusz Krol, Wroclaw University of Technology (Poland)

Jason J. Jung, Yeungnam University (Korea, Republic of)

Paul Davidsson, Blekinge Institute of Technology (Sweden)

Longbing Cao, University of Technology, Sydney (Australia)

Huaifeng Zhang, University of Technology, Sydney (Australia)

Qian Yin, Beijing Normal University (China)

\section{Session Chairs}

$1 \quad$ Image Processing in Agricultural Engineering Qi Luo, Wuhan Institute of Technology (China)

2 Photonics in Agricultural Engineering

Qi Luo, Wuhan Institute of Technology (China)

3 GIS, GPS, RS in Agricultural Engineering

Weitao Zheng, Wuhan University of Technology (China)

$4 \quad$ Wireless and Optical Communications in Agricultural Engineering Honghua Tan, Wuhan Institute of Technology (China)

5 Agricultural Decision Support and Simulation Systems Honghua Tan, Wuhan Institute of Technology (China)

6 Intelligent Monitoring and Control/ICT Applications in Rural Areas Honghua Tan, Wuhan Institute of Technology (China) 
$7 \quad$ Sensor Technology in Agricultural Engineering

Weitao Zheng, Wuhan University of Technology (China)

8 Other Related Information Technology in Agricultural Engineering Honghua Tan, Wuhan Institute of Technology (China) 


\section{Introduction}

Information technologies such as image processing, photonics, GIS, and so on are becoming more and more important for rural development. All commercial crop and animal production systems are potential users for intelligent Information technology products. Many intelligent information technology systems have been developed to help farmers, extension workers, and administrators. Intelligent information technology will provide powerful means for the transformation of agriculture. Many countries have established associations or research centers for information technology in agriculture. It is necessary for experts from developed and developing countries to exchange ideas.

Welcome to the PIAGENG 2009 conference, held 11-12 July 2009, in Zhangjiajie, China. The 2009 International Conference on Photonics and Image in Agriculture Engineering is cosponsored by the Intelligent Information Technology Application Research Association (IITA Association), IEEE SMC TC on Education Technology and Training (USA), the Wuhan Institute of Technology (China), and Asia Pacific Human-Computer Interaction Research Center of Hong Kong. PIAGENG 2009 has seven sessions: Image Processing in Agricultural Engineering; Photonics in Agricultural Engineering; GIS, GPS, RS in Agricultural Engineering; Wireless and Optical Communications in Agricultural Engineering; Agricultural Decision Support and Simulation Systems; Intelligent Monitoring and Control/ICT Applications in Rural Areas; Sensor Technology in Agricultural Engineering; and Other related information technology in Agricultural Engineering.

The purpose of PIAGENG 2009 is to bring together researchers and practitioners from academia, industry, and government to exchange their research ideas and results, and to discuss the state of the art in the areas of the conference.

We thank the SPIE staff for their enthusiastic support our conference, and for their editorial work on these proceedings. We would also like to thank the program chairs, organization staff, and the members of the program committees for their hard work.

We hope that PIAGENG 2009 will be successful and enjoyable to all participants. We look forward to seeing all of you next year at the PIAGENG 2010.

Honghua Tan 
Downloaded From: https://www.spiedigitallibrary.org/conference-proceedings-of-spie on 25 Apr 2023

Terms of Use: https://www.spiedigitallibrary.org/terms-of-use 